\title{
Islamic financial literacy scale: an amendment in the sphere of contemporary financial literacy
}

\author{
Yusuf Dinc, Mehmet Çetin, Mehmet Bulut and Rashed Jahangir \\ Istanbul Sabahattin Zaim University, Istanbul, Turkey
}

\begin{abstract}
Purpose - This study aims to develop a valid and reliable Islamic financial literacy (IFL) scale that can capture all the segments of the Islamic financial sectors and which could be considered applicable for all jurisdictions across the globe.

Design/methodology/approach - To build the measure, this study followed a scale development process by collecting 698 a priori items from 81 respondents. Later, it generated an item pool through the analysis of the items with experts and gave the last form ( 40 items) to 287 respondents in Turkey with another IFL scale that is frequently used in the literature and a scale assessing religiosity. With explanatory factor analysis, the scale demonstrates a four-factor construct with 20 items. This construct provides good fit indexes and reliability scores.

Findings - Results of the correlation analysis and comparison of the fit indexes of alternative structures provided supportive evidence for discriminant and convergent validity of the scale and its sub-dimensions. As a result, an applicable scale is developed for countries where Islamic financial institutions are operating and where they are not.

Originality/value - One of the strengths of this study is that it represents a comprehensive scale development for the entire Islamic financial system, including banking, taka $f u l$ (Islamic insurance) and fund management. In addition, the attempt to design an IFL scale applicable to any economy or individual is a pioneering attempt in the literature.
\end{abstract}

Keywords Islamic banking, Islamic finance, Islamic insurance, Literacy, Takāful

Paper type Research paper

\section{Introduction}

According to the Organization for Economic Co-operation and Development (OECD), financial literacy is "a combination of awareness, knowledge, skills, attitude and behavior necessary to make sound financial decisions and ultimately achieve individual financial well-being" (OECD INFE, 2011, p. 3). In other words, it is the capability of understanding and using finance-related information (Huston, 2010; Lusardi and Mitchell, 2014; Klapper et al., 2015).

Increasing financial literacy is considered one of the key factors in the growth and development of an economy. It is for this reason that many economies and multinational organizations (e.g. the World Bank) invest in projects to improve financial literacy in the

(C) Yusuf Dinc, Mehmet Çetin, Mehmet Bulut and Rashed Jahangir. Published in ISRA International Journal of Islamic Finance. Published by Emerald Publishing Limited. This article is published under the Creative Commons Attribution (CC BY 4.0) licence. Anyone may reproduce, distribute, translate and create derivative works of this article (for both commercial and non-commercial purposes), subject to full attribution to the original publication and authors. The full terms of this licence maybe seen at http://creativecommons.org/licences/by/4.0/legalcode

Received 29 July 2020 Revised 17 September 2020 20 January 2021 18 March 2021

19 April 2021 Accepted 7 May 2021
Islamic financial literacy scale 
society for better overall economic performance (Xu and Zia, 2012). Improvement in financial literacy is assumed to increase financial inclusion and funds' circulation, resulting in better economic performance. However, the financial literacy concept is mostly developed on an interest-based financial concept. Accordingly, it can be said that the effort to introduce financial literacy has an aim of making the concept of interest acceptable in societies. This is despite the fact that interest is strongly prohibited in every religion. Even in secular jurisdictions, it is practiced and acknowledged only in the banking sector as an exception. Borhan (2009) discussed the rationale behind the prohibition of rib $\bar{a}$ (interest) in an economy by focusing on the aspects of savings and capital formation, profitability and productivity and unemployment and inflation. Besides, the concept of $r i b \bar{a}$ is criticized for disparities in income and wealth distribution, resulting in worsening economic justice instead of social well-being.

This economic injustice and disproportionate distribution of income or returns have created reasonable doubt and raised questions among experts (and even among laypersons) about the concept of $r i b \bar{a}$ and its widespread use in the entire economic system. For instance, are we to accept the supposition in financial literacy discourses that interest-oriented investments are ethical when interest is a means for capitalist monopolization? Should we accept the teaching of the concept of interest in math courses as normal? Should financial literacy discussions of the concept of interest in investments be taken as a means of achieving submission to the capitalist system? Unfortunately, increasing financial literacy makes people (or their assets) part of the financial system for the advantage of capitalists instead of representing sensitization campaigns to what is beneficial or harmful for the society.

For that reason, Muslims should acquire Islamic financial literacy (IFL); they should have enough financial knowledge within the attitudinal framework that one should ideally behave for the good of humankind. Indeed, this kind of financial literacy may enable people (particularly Muslims) to understand Sharī'ah non-compliant practices in Islamic financial institutions and manage Sharīah non-compliant risk, i.e. the possibility of Sharīah noncompliance in Islamic financial transactions (Bhatti, 2020). Besides, acquiring IFL will strengthen the foundation of ethics and morality (which were left out from the field of study) in the contemporary field of economics and finance. Masudul and Choudhury (2020) argued in favor of the necessity of ethics and morality in the study of economics and finance. The main difference between the philosophy of conventional financial literacy and IFL is the orientation of the individual or the society in the involvement in the interest-based transaction. In addition, the concept of interest also differentiates between these two financial literacy scales.

The prohibition of interest should make Muslims more creative in developing a social financial system, as Moghul (2019) discussed during a panel on Islamic finance in Istanbul. Because interest is prohibited in Islam, Muslims should have developed a clear understanding of the concept of interest, e.g. why is it prohibited, and what are the real alternatives to it? An answer to the latter would require specialization in math for financial engineering. Besides, they should have institutionalized the best practices and introduced standard rules and regulations. The world would have been a completely different place (in a positive sense) if these had been done systematically soon after the farewell sermon of Prophet Muhammad (peace be upon him).

IFL has come into the limelight in the past ten years. However, the philosophy of the Islamic finance concept has not been reflected in many of the developed measurement scales. Simultaneously, there has been no project whatsoever to propose an appropriate scale on the multi-country level, except the Islamic "banking-only" literacy scales. In other words, a 
comprehensive IFL scale is absent in the literature that covers all the segments of Islamic finance such as banking, insurance, capital markets and any other Sharī'ah-compliant financial model.

This research is conducted to fill the literature gap. The main objective of this study is to develop an IFL scale which covers all the segments of the Islamic financial sector which would be applicable to any country, even those that are not familiar with the current Islamic finance practice. To obtain a vibrant finding, it collected 287 responses from respondents in a significant number of cities in Turkey.

The remaining part of the study is organized as follows. The second section reviews the relevant literature. The third section discusses the method of IFL scale development. It is followed by the analysis of the results of the study. The last section concludes the paper.

\section{Literature review}

Voluminous literature has been written on the theme of IFL. In this cornucopia of literature, each study analyses the concept of IFL based on a unique objective, which makes a review of the literature arduous. However, this study carefully separates these past studies based on the perspective of researchers, classifying them into three sections: level of IFL among students, factors affecting financial literacy and IFL index.

\section{Level of Islamic financial literacy among students}

Alfarisi (2020) analyzed the impact of courses relating to Islamic economics and finance on the level of IFL among university students; the study showed a significant impact of specifically introduced courses on the level of Islamic financial knowledge or literacy. A similar study by Md and Ahmad (2020) showed that courses offered to Muslim undergraduate students in Malaysia significantly impact their scores of general financial literacy. Some studies have identified factors that influence the level of students' IFL. For instance, Abdullah et al. (2017) suggested three factors: gender, education level and attitude to financial management. On the other hand, Rahim et al. (2016) listed the factors that influence IFL among university students, identifying them to be religiosity, financial satisfaction and hopelessness. Noticeably, a study focusing on the IFL level of a sample group of enrolled students in Islamic economics and business faculty revealed that "age" is the only factor that affects the level of literacy (Hisan, 2019). There is a void in the literature regarding the other possible antecedents of the IFL concept.

Bley and Kuehn (2004) analyzed student knowledge and perception of both conventional and Islamic banking in the United Arab Emirates by analyzing 667 graduate and undergraduate business students' responses. The findings revealed that the selected students have higher knowledge about conventional banking terms and concepts than those of Islamic banking. Hafizah and Rahim (2014) examined the undergraduate students' level of IFL in terms of Islamic finance and banking at University Utara Malaysia, along with an analysis of the impact of psychological determinants (religiosity, hopelessness and financial satisfaction) and gender on IFL. They relied on a sample of 200 respondents' responses. The findings showed a high IFL among the selected students, with male students having a higher financial literacy rate compared to female students. Besides, it revealed that psychological determinants have a significant influence on IFL.

From the previously mentioned literature, it can be derived that students who take Islamic economics and finance courses are more literate in terms of Islamic finance compared to other students, which is expected and normal. Noticeably, the age of students plays a vital role in this literacy level. 
IJIF

13,2

Factors affecting financial literacy

Regarding the factors affecting financial literacy, Abdullah and Chong (2014) examined whether adequate research is available on financial literacy in terms of Islamic financial products and services, as well as variations in variables affecting individuals' financial literacy. The findings revealed that very little research had been conducted regarding financial literacy in terms of Islamic financial products and services. Moreover, the literature on the financial literacy of people in terms of their preference of banking products and services was absent. However, Sardiana (2016) found that IFL has a significant influence on people's preference for Islamic financial services. Precisely, knowledge was found to be the factor that has a partial influence on people's preference for considering Islamic financial services. Fraczek and Klimontowicz (2015) in a similar study found that basic knowledge of finance influences the decision of young customers in terms of financial and banking products preference. Ahmad et al. (2020) investigated the determinants of IFL and extracted two factors: "subjective knowledge of Sharī'ah compliance"; and "knowledge of $r i b \bar{a}$ and profit-sharing concept."

Abdullah and Anderson (2015) examined bankers' financial literacy regarding financial decisions related to Islamic products and services; they identified the significant variables that affect the bankers' IFL by applying factor analysis. The findings revealed that nine variables influence bankers' financial literacy in terms of Islamic products and services. Besides, Zaman et al. (2017) investigated the level of IFL among the residents of Lahore in terms of the adoption of Islamic banking services. The result showed that most of the respondents are concerned about the legitimacy of Islamic banking services, quality of customers, operational legitimacy of the Islamic banking system and quality of products and services. The study also found that the legitimacy of the Islamic banking system, level of education, customer services and quality of services affect the adoption rate of Islamic banking services.

\section{Islamic financial literacy index}

Albaity and Rahman (2019) examined whether or not factors such as IFL, "awareness," "reputation and attitude toward Islamic banking" and "cost and benefit" influence the customers' decision to use or not Islamic banking. Surprisingly, they found a significantly negative correlation between customers' intention to use Islamic banking and IFL. Noticeably, this is the only pair that is significantly and negatively correlated, whereas the others are insignificantly correlated. Widityani et al. (2020) proposed three variables that develop college students' IFL: attitude, perception and knowledge and behavior. They also claimed that the IFL index differs based on the level of education and gender and that the IFL index is higher for the students who have taken Islamic finance-related courses and the preference for Islamic financial products is higher for the students who have a higher IFL index.

The aforementioned studies have focused on the students' IFL level and factors affecting financial literacy. Despite having numerous studies in the field of IFL, the literature related to IFL indexing is quite limited. In the following paragraphs, the study exclusively concentrates on summarizing the literature related to IFL indexing.

Er and Mutlu (2017) conducted a survey study with 388 participants in Trabzon, a city of Turkey and developed a general index of IFL along with three sub-indexes, i.e. "IFL information index, IFL attitudinal index, IFL behavioral index." The result revealed the general Islamic financial index to be $58 \%$. Hidajat and Hamdani (2015) analyzed the development of the IFL index from the perspective of experts and practitioners. The data regarding "knowledge" are collected from the opinions of experts, and the data related to the "ability to use" are obtained from the opinions of practitioners. Antara and Musa (2020) applied Rasch analysis to develop an instrument that is reliable and valid to measure IFL 
among Muslim urban millennial (MUM) generations, and they successfully developed the scale. However, the result showed a bias between the genders in terms of three items.

Nawi et al. (2018) investigated the IFL concept and suggested appropriate items for its measurement. The result of the study showed the development of the proposed measurement items of IFL as well as the construction of various questions related to Islamic banking, money basics, Sharī'ah-compliant investments and takäful. Antara et al. (2016) focused on hatāl literacy and IFL. They proposed a measurement and validity approach for hatal literacy and IFL that may facilitate policymakers comprehending the literacy level of customers.

Although there are reliable scales for measuring IFL, especially Islamic banking literacy, which can be used in countries and societies that are familiar with Islam and the concepts of the belief system, a scale is still absent for measuring the attitudes toward Islamic finance on the part of individuals who are not familiar with it. Besides, most of the current literacy scales only address Islamic banking instead of Islamic finance as a whole, which is one of the significant gaps in the previous literature. This study fills in the gap and develops a scale for IFL that covers not only the banking sector but the entire Islamic financial sector.

\section{Methodology}

\section{General method}

The level of financial literacy is mostly measured by a scale of three dimensions, i.e. attitude, behavior and knowledge (Atkinson et al., 2007; Willis, 2008; Shim et al., 2009; Jorgensen and Savla, 2010). These dimensions have been known for centuries and are applicable for measuring literacy in any subject area. Al-Ghazali (1058-1111 CE) notably highlighted this trinity in his works (Orman, 2018). However, some studies have applied different dimensions for measuring financial literacy. For instance, Fraczek and Klimontowicz (2015) indicated an ideal combination of six dimensions (awareness, understanding, skill, knowledge, behavior and attitude) which, as they claimed, are essential to take a proper financial decision as well as achieve financial well-being of an individual. On the other hand, the Financial Services Authority (2013) of Indonesia considered three dimensions (knowledge, skills and confidence) for the financial literacy scale, where the dimensions are measured based on the financial institution and its products and services.

In the process of developing an IFL scale, this study followed the steps recommended by DeVellis (2003). First, an item pool was created (as will be described in detail in the following parts) that was built on the extant literature and using the open-ended survey method. Later, focus group studies were conducted to cluster and screen the items generated by the respondents. Then, the research proceeded to create the last form for the measure to use in the analysis where the following were tested: the factor structure, reliability and validity of the new measure. After the clustering and screening process, the last form was distributed to a new group of respondents $(\mathrm{N}=287)$ in Turkey with a scale, which is suggested by Antara et al. (2016) and later translated to Turkish by Çömlekçi (2017). The scale is frequently used to assess IFL for comparison and the convergent validity. The religiosity measure was also used to evaluate the discriminant validity of the new scale (Allport and Ross, 1967). Ok (2011) adapted the religiosity scale to Turkish. After the validity test, explanatory factor analysis was used to explore the factor structure of the scale and confirmatory factor analysis (CFA) was used for the extant scales as well as the last form of the developed scale. Besides, the researchers proceeded by calculating the Cronbach's alpha scores for the measures and their dimensions, and they compared the one-factor structure model and four-factor structure model for the new measure. At the end of the procedure, the correlations between the scales and their dimensions were assessed. 
$\mathrm{IJIF}$

13,2

\section{Item generation}

Before creating the item pool for the scale, the study reviewed a significant amount of literature and collected definitions for the concept. Then, it analyzed the threedimension OECD INFE methodology and other scales for developing the survey form and critically followed a prohibition-based approach from the haram (forbidden) perspective of maqūsid al-Sharī ah (objectives of Sharī'ah), mainly generated around four main principles of Islamic finance. In particular, eliminating gharar (risk, uncertainty, deceit and hazard), eliminating qimār (gambling), avoiding the financing of restricted goods and services and prohibition of interest underpin the philosophy of this study's scale development process.

In this item generation process, the study operationalized a definition for IFL and provided this definition with an instruction that asks for possible example items for each dimension of the concept (knowledge, skill and attitude). Later, the concept was operationalized under knowledge, attitude and skill dimensions and kept the responders free to write any items, even items that are not under these given dimensions. In this process, it collected 698 example items from 81 (of 120 field expert) respondents. After screening irrelevant items and combining the ones expressing the same meaning with different words, 200 items were selected and evaluated in focus group studies, consisting of Islamic economics scholars. Each item was discussed carefully with a group of scholars; this process helped to purify and validate the respondents' items. Three focus group studies were conducted with 11 scholars in total, with some of the items being integrated, while others were eliminated. The remaining 40 items were provided in a form to respondents to assess the compatibility of the items with the concept and its dimensions. After the assessment, the same 40 items were selected for the last form of the scale, where the paper conducted a factor analysis and tested for discriminant and convergent validities.

\section{Sample}

The last form of the current scale (with 40 items) was given to 287 respondents with the religiosity measure (Allport and Ross, 1967) and the IFL scale developed by Antara et al. (2016). Most of the respondents are male (59\%), between the ages of 25 and 34 $(>70 \%)$, have a bachelor's degree $(>60 \%)$ and are salaried employees in the private sector. The respondents were also asked about their financial institution preference, and most of them chose interest-free financial institutions.

\section{Measures}

Religiosity scale. The religiosity scale developed by Allport and Ross (1967) was used to measure the level of religiousness of the respondents in terms of three different dimensions. The scale consists of 21 items measuring intrinsic religiosity, spiritual well-being-oriented religiosity and social-oriented religiosity. Ok (2011) translated the scale into Turkish, validated it, and provided high-reliability scores for the measure and its dimensions.

Islamic financial literacy scale. The IFL scale developed by Antara et al. (2016) was used to measure the level of IFL of the respondents in three different dimensions to compare it with the ones that this study developed. The dimensions of this scale are Islamic financial attitude, behavior and knowledge. Çömlekçi (2017) adapted the scale to Turkish. Highreliability scores were calculated for the measure and its dimensions. 


\section{Results and discussion}

Explanatory factor analysis of Islamic financial literacy scale

Explanatory factor analysis was conducted to explore the factor structure of the scale. First, the study tested whether the selected sample was sufficient enough for conducting factor analysis. Kaiser-Myer-Olkin (KMO) (0.861) and Bartlett test results (0.000) demonstrated that the data were proper for the factor analysis. Alongside, it used principal components and varimax rotation method and calculated factors that are larger than 1 in Eigenvalue. Items with lower than 0.5 factor loadings were eliminated. The last form of the scale depicted a four-factor structure. The results are given in Table 1.

\section{Reliability analysis for the measures of the study}

Results of the explanatory factor analysis indicated that a four-factor structure is formed, and the factors are shaped as Islamic financial behavior, knowledge, attitude and awareness. These four-factors together explain $60 \%$ of the variance in the variable in total. All factor loadings are larger than 0.50 and reliability statistics (Cronbach's alpha scores) are calculated for the scale and its dimensions. Table 2 depicts the Cronbach's alpha scores for

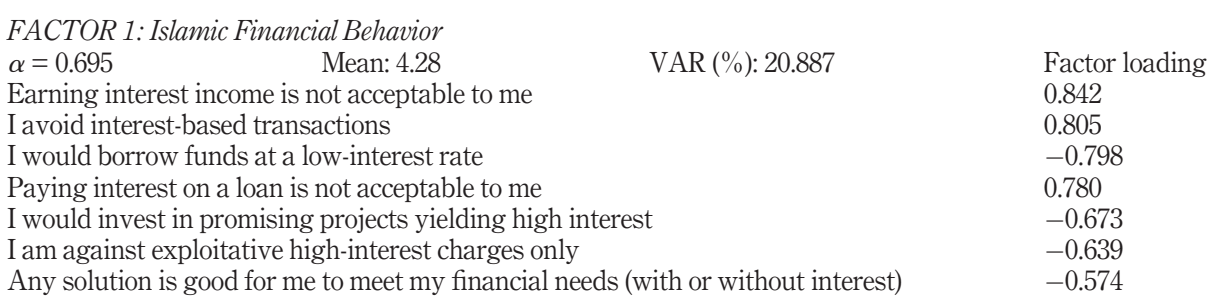

FACTOR 2: Islamic Financial Knowledge
$\alpha=0.870$
Mean: 4.22
VAR (\%): 18.942

Investing in a business where contract terms are not clearly defined is not acceptable

Factor loading Investing in a business that is harmful to people and the environment is not acceptable

0.755

0.746

There are alternative interest-free institutions and instruments for the investment of savings 0.727

I can save until I accumulate a targeted amount of funds

0.713

I can manage my funds without engaging in interest

0.708

Interest disrupts income distribution

0.630

Interest has a negative and undesirable impact on the economy

0.517

FACTOR 3: Islamic Financial Attitude
$\alpha=0.787$
Mean: 3.27
$\operatorname{VAR}(\%): 11.288$
Factor loading
A loan should not be given to generate income
0.683
0.679
People should help each other in overcoming difficulties
$\begin{array}{ll}\text { People should support each other financially } & 0.627\end{array}$
The purpose of borrowing should be known to the creditor 0.589

\section{FACTOR 4: Islamic Financial Awareness}

$\alpha=0.848 \quad$ Mean: 4.26

VAR (\%): $8.926 \quad$ Factor loading

I don't mind inviting others to be partners in my business

I would invest and become a partner in a business

0.869

0.852

Table 1.

Kaiser-Meyer-Olkin test of sample adequacy: 0.861

Results of

Chi-Square: 2,710,760 df: 190 Significance: 0.000

Total variance explained: $60.04 \%$

explanatory factor analysis for Islamic

financial literacy

Source: Authors' computation scale 
F4: Islamic financial awareness

Islamic Financial (Banking) Literacy Scale (Antara et al., 2016) 0.942

Islamic financial attitude (Antara et al., 2016)

Table 2.

Reliability statistics for the scales used in the study

\section{Secular religiosity}

Socially oriented religiosity

Spiritual well-being-oriented religiosity

0.649

0.816

0.837

Source: Authors' computation

the dimensions of the scale and the scale as a whole. All dimensions and the scale itself show adequate to high reliabilities, and items 9, 12, 13, 14, 15 are reverse-coded.

Reliability scores for the other measures and their dimensions that are used in the study are also given in Table 2. All reliability scores are indicative of high reliability for the measures.

\section{Confirmatory factor analysis for the scales used in the study}

This study's factor structure resulting from the explanatory factor analysis was tested with CFA. In CFA, the fit indexes are indicative of the properness of the scale (Hu and Bentler, 1995; Schumacker and Lomax, 2004). Fit indexes of the four-factor model were calculated using CFA. Results from this analysis indicate good fit for the measure $\left(\chi^{2} / \mathrm{df}=1,705, \mathrm{CFI}=0.96, \mathrm{IFI}=\right.$ $0.96, \mathrm{TLI}=0.95, \mathrm{GFI}=0.92, \mathrm{RMSEA}=0.05$ ).

For testing whether or not this four-dimension structure is the proper form for the scale, the study also compared this structure with an alternative structure where all items were taken as one dimension. It compared one-factor and four-factor structure models for the new measure. The CFA for the structure of the scale reveals that this 4-factor model fits better than the one-factor model $\left(\chi^{2} / \mathrm{df}=5,657, \mathrm{CFI}=0.70\right.$, IFI $=0.70, \mathrm{TLI}=0.66, \mathrm{GFI}=0.68$, RMSEA $=0.128)$. Table 3 presents the fit indexes for the measures used in the analyses.

Furthermore, the paper used CFA to test the fits of the existing religiosity scale (Allport and Ross, 1967) and the IFL scale developed by Antara et al. (2016). Fit indexes indicated a good fit for these scales, and thus the study followed other analyses with the dimensions and structure as in the original scales.

Table 3.

Fit indexes for the scales used in the study

\begin{tabular}{lcccccc}
\hline Particulars & $\chi^{2} / \mathrm{df}$ & CFI & IFI & TLI & GFI & RMSEA \\
\hline 1. Islamic Financial Literacy Scale (DC) (4-factor structure) & 1.705 & 0.96 & 0.96 & 0.95 & 0.92 & 0.05 \\
2. Islamic Financial Literacy Scale (DC) (1-factor structure) & 5.657 & 0.70 & 0.70 & 0.66 & 0.68 & 0.128 \\
2. Islamic Financial Literacy Scale (OC) & 2.39 & 0.90 & 0.90 & 0.90 & 0.81 & 0.07 \\
3. Religiosity Scale & 2.05 & 0.93 & 0.92 & 0.91 & 0.90 & 0.06
\end{tabular}

Notes: $\mathrm{DC}=$ developed scale; $\mathrm{OC}=$ other scale (Antara et al., 2016)

Source: Authors' computation 
Convergent validity can be defined as "substantial relations with other purported measures of the target construct" (Watson et al., 1995, p. 5). Discriminant and convergent validity refer to a condition when two different measures of the same variable are highly correlated but when they are taken with other constructs they correlate less strongly (Lehmann, 1988, p. 411).

To check for convergent and discriminant validities of the scale and the sub-scales, the study distributed our scale with another measure developed for assessing the same construct (Antara et al., 2016) and a scale that measures dimensions of religiosity. For convergent and discriminant validities, the study seeks proper correlations with the existing valid and reliable scales in the literature (Antara et al., 2016).

Firstly, the paper calculated the Pearson correlation coefficients for the interrelations between the sub-dimensions of the scale. The scores indicate that the parts that generate the construct are correlated with each other significantly and adequately. None of the correlations between the dimensions exceeds 0.70 , which indicates that the dimensions are independent constructs.

Significant correlations among the sub-dimensions of the newly developed scale and the existing scale that was developed by Antara et al. (2016) indicate a convergent validity for the new measurement instrument. Weaker correlations between the newly developed scale and dimensions of extrinsic religiosity (spiritual well-being-oriented religiosity, socialoriented religiosity) are also indicative of discriminant validity.

On the other hand, significant positive correlations between the components of the scale and intrinsic religiosity on the one hand and significantly weaker or negative correlations between the components of the scale and secular religiosity on the other hand are also indicators for validity. These findings are consistent with the findings of extant studies (Luthfiani and Sari, 2019) (Table 4).

\section{Conclusion}

Recently, a considerable amount of literature has evolved on the theme of IFL. However, the scaling of its literacy remained a significant challenge. To date, IFL is yet to be systematically examined. Previous studies of IFL have suffered a lack of segment sensitivity and notable methodological weaknesses.

This study attempts to develop and validate an IFL scale that is compatible with the principles of Islamic finance and its different segments, contrary to the previous studies' focus on Islamic banking only. The present research explores, for the first time, scaling IFL for all industry segments.

Using the extant literature, the study provided definitions for IFL and its components. It created an item pool by using focus group studies and analysis of the responses from participants, which shaped our operational factors. Besides, the study tested the reliability of our scale and compared the fit of its structure to its forms of fewer dimensions and other extant scales. Findings indicate a good fit and high reliability for the scale. It also tested the convergent and discriminant validity using an extant frequently used scale and a scale for measuring religiosity levels in different dimensions. The outcome of the dimensions contradicts previous three-dimension studies and introduces one additional dimension called awareness. It can be said that the awareness dimension derives risk-sharing aspects. Findings demonstrate adequate intercorrelations among the dimensions of the scale with proper and significant correlations to the comparison scale. It is hoped that this research will contribute to a deeper understanding of the IFL concept.

Although this pattern of findings is indicative of a valid and reliable measurement device, further studies will elaborate on the usefulness of the scale. It is believed that 
IJIF

13,2

260

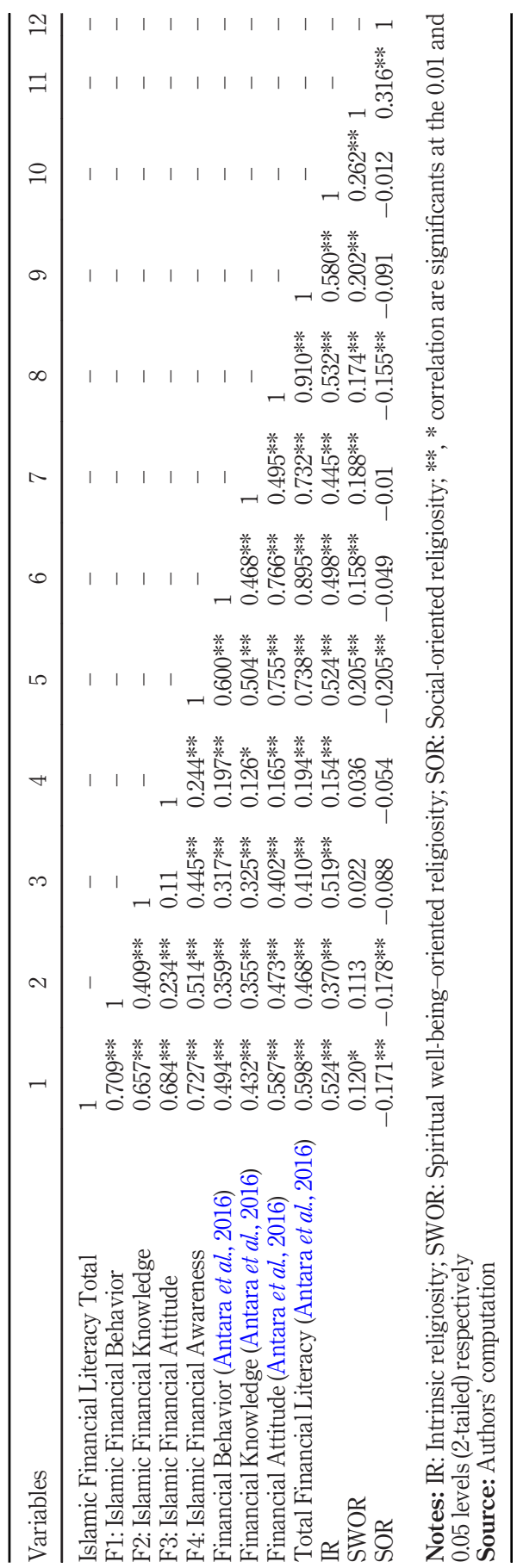

Table 4.

Correlation analysis 
researchers (addressing Turkey and countries with different cultural and contextual aspects) could use this scale as a well-designed option of measurement.

The findings of the study have important implications for developing an efficient IFL scale. The approach of this research and the developed scale allow measuring the IFL level even in jurisdictions that do not yet have any investments in Islamic finance. The theoretical implication of this study is that an optimum IFL scale needs the fourth dimension, i.e. awareness, compared to conventional financial literacy scales. It can be said that being relatively new is the reason behind the fourth dimension. IFL plays a critical role while the interest-based models have already started to be excluded from modern economies. Indeed, IFL is the direct opposite of conventional financial literacy, and it is needed for creating awareness about the benefits of Islamic economics and finance.

\section{References}

Abdullah, M.A., Ab Wahab, S.N.A., Sabar, S. and Abu, F. (2017), "Factors determining Islamic financial literacy among undergraduates", Journal of Emerging Economies and Islamic Research, Vol. 5 No. 2, pp. 67-76.

Abdullah, M.A. and Anderson, A. (2015), "Islamic financial literacy among bankers in Kuala Lumpur", Journal of Emerging Economies and Islamic Research, Vol. 3 No. 2, pp. 79-94.

Abdullah, M.A. and Chong, R. (2014), "Financial literacy: an exploratory review of the literature and future research", Journal of Emerging Economies and Islamic Research, Vol. 2 No. 3, pp. 32-41.

Ahmad, G., Widyastuti, U., Susanti, S. and Mukhibad, H. (2020), "Determinants of the Islamic financial literacy", Accounting, Vol. 6 No. 6, pp. 961-966.

Albaity, M. and Rahman, M. (2019), "The intention to use Islamic banking: an exploratory study to measure Islamic financial literacy", International Journal of Emerging Markets, Vol. 14 No. 5, pp. 988-1012.

Alfarisi, M.F. (2020), "The impact of Islamic economics and finance courses on Islamic financial literacy of university students", paper presented at The 3rd International Conference on Sustainability and Innovation.

Allport, G.W. and Ross, J.M. (1967), "Personal religious orientation and prejudice", Journal of Personality and Social Psychology, Vol. 5 No. 4, pp. 432-443.

Antara, P.M. and Musa, R. (2020), "Validating Islamic financial literacy instruments among mum generation: Rasch analysis approach”, International Journal of Business and Society, Vol. 21 No. 3, pp. 1113-1121.

Antara, P.M., Musa, R. and Hassan, F. (2016), "Bridging Islamic financial literacy and halal literacy: the way forward in halal ecosystem”, Procedia Economics and Finance, Vol. 37, pp. 196-202.

Atkinson, A., McKay, S., Collard, S. and Kempson, E. (2007), "Levels of financial capability in the UK", Public Money and Management, Vol. 27 No. 1, pp. 29-36.

Bhatti, M. (2020), "Managing Shari'ah non-compliance risk via Islamic dispute resolution", Journal of Risk and Financial Management, Vol. 13 No. 1, pp. 1-9.

Bley, J. and Kuehn, K. (2004), “Conventional versus Islamic finance: student knowledge and perception in the United Arab Emirates", International Journal of Islamic Financial Services, Vol. 5 No. 4, pp. 17-30.

Borhan, J.T. (2009), "Rationale and consequences of the prohibition of riba in an Islamic economic system”, Innovatio, Vol. 8 No. 2, pp. 291-312.

Çömlekçi, İ. (2017), "İslami finansal okuryazarlik düzeyinin belirlenmesi: Katilim Bankalari müşterileri üzerine bir araştirma”, Elektronik Sosyal Bilimler Dergisi, Vol. 16 No. 63, pp. 1423-1439.

DeVellis, R.F. (2003), Scale Development: Theory and Applications, 2nd ed., Sage, Thousand Oaks, CA. 
$\mathrm{IJIF}$

13,2

262

Er, B. and Mutlu, M. (2017), "Financial inclusion and Islamic finance: a survey of Islamic financial literacy index", Uluslararasi Islam Ekonomisive Finansı Araştrmalan Dergisi, Vol. 3 No. 2, pp. 33-54.

Financial Services Authority (2013), Kerangka Strategi Nasional Literasi Keuangan Indonesia, FSA, Indonesia.

Fraczek, B. and Klimontowicz, M. (2015), "Financial literacy and its influence on young customers' decision factors", Journal of Innovation Management, Vol. 3 No. 1, pp. 62-84.

Hafizah, S. and Rahim, A. (2014), "Psychosocial factors and gender influencing the level of Islamic financial literacy", Doctoral dissertation, Universiti Utara Malaysia.

Hidajat, T. and Hamdani, M. (2015), "Developing Islamic financial literacy index: a conceptual paper", paper presented at The Global Advanced Research Conference on Management and Business Studies.

Hisan, K. (2019), "Islamic financial literacy among students attending faculty of Islamic economics and business", Ihtiyath: Jurnal Manajemen Keuangan Syariah, Vol. 3 No. 2, pp. 113-122.

Hu, L.T. and Bentler, P.M. (1995), Evaluating Model Fit. Structural Equation Modeling: Concepts, Issues and Application, Sage, Thousand Oaks, CA.

Huston, S.J. (2010), "Measuring financial literacy", Journal of Consumer Affairs, Vol. 44 No. 2, pp. 296-316.

Jorgensen, B.L. and Savla, J. (2010), "Financial literacy of young adults: the importance of parental socialization", Family Relations, Vol. 59 No. 4, pp. 465-478.

Klapper, L., Lusardi, A. and Van Oudheusden, P. (2015), Financial Literacy around the World: Insights from the Standard and Poor's Ratings Services Global Financial Literacy Survey, Global Financial Literacy Excellence Center, The George Washington, DC University.

Lehmann, D.R. (1988), "An alternative procedure for assessing convergent and discriminant validity", Applied Psychological Measurement, Vol. 12 No. 4, pp. 411-423.

Lusardi, A. and Mitchell, O.S. (2014), "The economic importance of financial literacy: theory and evidence", Journal of Economic Literature, Vol. 52 No. 1, pp. 5-44.

Luthfiani, R.A. and Sari, R.C. (2019), "The effect of religiosity, the level of income, and the level of Islamic financial literacy toward the interest of student to become customers in Sharia financial institution", Nominal: Barometer Riset Akuntansi Dan Manajemen, Vol. 8 No. 1, pp. 109-121.

Masudul, A. and Choudhury, B. (2020), Heterodox Islamic Economics: The Emergence of an EthicoEconomic Theory, Routledge, New York, NY.

Md, A.S. and Ahmad, W.M.W. (2020), "Financial literacy among Malaysian Muslim undergraduates", Journal of Islamic Accounting and Business Research, Vol. 11 No. 8, pp. 1515-1529.

Moghul, U. (2019), "A landmark impact investment: could this innovative experiment with Islamic finance provide a model for both sectors?", available at: https://nextbillion.net/impactinvestment-islamic-finance/ (accessed 2 September 2020).

Nawi, F.A.M., Daud, W.M.N.W., Ghazali, P.L., Yazid, A.S. and Shamsuddin, Z. (2018), "Islamic financial literacy: a conceptualization and proposed measurement", International Journal of Academic Research in Business and Social Sciences, Vol. 8 No. 12, pp. 629-641.

OECD INFE (2011), Measuring Financial Literacy: Core Questionnaire in Measuring Financial Literacy: Questionnaire and Guidance Notes for Conducting an Internationally Comparable Survey of Financial Literacy, OECD, Paris.

Ok, Ü. (2011), "Dini tutumölçeği: ölçekgeliştirmevegeçerlikçalışması", Uluslararası İnsan Bilimleri Dergisi, Vol. 8 No. 2, pp. 528-549.

Orman, S. (2018), Gazali, Adaletve Sosyal Adalet, Iktisad Yayinlari, Istanbul.

Rahim, S.H.A., Rashid, R.A. and Hamed, A.B. (2016), "Islamic financial literacy and its determinants among university students: an exploratory factor analysis", International Journal of Economics and Financial Issues, Vol. 6 No. 7S, pp. 32-35. 
Sardiana, A. (2016), "The impact of literacy to Shariah financial service preferences", ETIKONOMI, Vol. 15 No. 1, pp. 43-62.

Schumacker, R.E. and Lomax, R.G. (2004), A Beginner's Guide to Structural Equation Modeling, Lawrence Erlbaum Associates, Mahwah.

Shim, S., Xiao, J.J., Barber, B.L. and Lyons, A.C. (2009), "Pathways to life success: a conceptual model of financial well-being for young adults", Journal of Applied Developmental Psychology, Vol. 30 No. 6, pp. 708-723.

Watson, D., Weber, K., Assenheimer, J.S., Clark, L.A., Strauss, M.E. and McCormick, R.A. (1995), "Testing a tripartite model: evaluating the convergent and discriminant validity of anxiety and depression symptom scales", Journal of Abnormal Psychology, Vol. 104 No. 1, pp. 3-14.

Widityani, S.F., Faturohman, T., Rahadi, R.A. and Yulianti, Y. (2020), "Do socio-demographic characteristics and Islamic financial literacy matter for selecting Islamic financial products among college students in Indonesia?", Journal of Islamic Monetary Economics and Finance, Vol. 6 No. 1, pp. 51-76.

Willis, L.E. (2008), “Against financial-literacy education”, Iowa L. Rev, Vol. 94 No. 1, pp. 197-285.

Xu, L. and Zia, B. (2012), "Financial literacy around the world: an overview of the evidence with practical suggestions for the way forward", World Bank Policy Research Working Paper No. 6107, The World Bank, Washington, DC.

Zaman, Z., Mehmood, B., Aftab, R., Siddique, M.S. and Ameen, Y. (2017), "Role of Islamic financial literacy in the adoption of Islamic banking services: an empirical evidence from Lahore, Pakistan”, Journal of Islamic Business and Management, Vol. 7 No. 2, pp. 230-247.

\section{About the authors}

Yusuf Dinc, PhD, started his banking career at Albarakatürk Katılım Bank in 2007. He joined Duke University as a visiting scholar in 2015. Later, he served as an Assistant Professor at the University of Trakya from 2016 to 2017. Since then, he has been a faculty member (Associate Professor) at the Department of Islamic Economics and Finance in Istanbul Sabahattin Zaim University. He is also the Director of the Management, Entrepreneurship and Leadership Research Center. Yusuf Dinc is the corresponding author and can be contacted at: yusuf.dinc@izu.edu.tr

Mehmet Çetin, $\mathrm{PhD}$, completed his degrees in management and economics. He has a $\mathrm{PhD}$ in the field of organizational behavior. Dr Çetin has worked as a manager and management consultant. Currently, he is an academic at Istanbul Sabahattin Zaim University.

Mehmet Bulut, PhD, is the Rector of Istanbul Sabahattin Zaim University, Turkey, and a Professor at the Department of Islamic Finance and Economics. His areas of specialization include international political economy, Ottoman economics and civilization, Ottoman-European economic relations and waqf, among others.

Rashed Jahangir is a $\mathrm{PhD}$ candidate in Islamic economics and finance at Istanbul Sabahattin Zaim University. He has several publications and has presented a number of conference papers as well. His research interests include Islamic finance, capital markets, FinTech and ROSCA (Rotating Savings and Credit Association).

For instructions on how to order reprints of this article, please visit our website: www.emeraldgrouppublishing.com/licensing/reprints.htm Or contact us for further details: permissions@emeraldinsight.com 